\title{
GLACIATION OF OBSERVATION HILL, HUT POINT PENINSULA, ROSS ISLAND, ANTARGTIGA
}

\author{
By Robert B. Forbes \\ (Geology Department and Geophysical Institute, University of Alaska, College, Alaska, \\ U.S.A.) \\ and Donald W. Ester \\ (Geology Department, University of Alaska, College, Alaska, U.S.A.)
}

\begin{abstract}
East-west glacial striations and grooves were discovered on the summit ridge of Observation Hill, which parallel the present direction of shelf ice movement to the east and south-east of the Hut Point peninsula. This evidence suggests that Observation Hill may have been glaciated by a thickened McMurdo lobe of the adjacent Ross Ice Shelf, moving west, as it does today.

Résumé. On a découvert sur la crête du sommet de l'Observation Hill des sillons de direction parallèle au mouvement actuel de l'Ice Shelf à l'est et au sud-est de la presqu'ile Hut Point. Il est donc probable que l'Observation Hill était englacée dans la région de McMurdo, par un lobe plus épais du Ross Ice Shelf, se déplacant vers l'Ouest comme il le fait aujourd'hui.

Zusammenfassung. Am Gipfelgrat des Observation Hill wurden in west-östlicher Richtung verlaufende glaziale Furehungen festgestellt, parallel zu den rezenten Bewegungen des Ice Shelf östlich und südöstlich der Hut Point-Halbinsel. Dies lässt vermuten, dass der Observation Hill im Gebiet der McMurdo Sound von einer ursprünglich mächtigeren Zunge des benachbarten Ross Ice Shelf erfasst wurde, die sich wie heutzutage nach Westen bewegte.
\end{abstract}

\section{INTRODUCTION}

In December ig62, we found east-west trending glacial striations and grooves on the summit ridge of Observation Hill, adjacent to McMurdo Naval Air Facility (Figs. I and 2).

Observation Hill is a familiar landmark to those who have worked and visited in the McMurdo Sound region, and it is often climbed by personnel wishing to visit Scott's cross, which is on the summit.

Observation Hill has been discussed previously by Ferrar (1907), David and Priestley (1914), Taylor (1922) and Debenham (1923). These authors have treated Observation Hill and the "Gap" (Fig. 2) as glaciated landforms, but we have found no reference to glacial striations and/or grooves in these discussions.

\section{Location and Description of Lineations}

Striations (Fig. 3) were found at four localities on the outcrops of trachyte which form the summit ridge (shown as localities Nos. 1, 2, 3, and 4 on Figure 5 A). Locality No. 4 also displays deep grooves which transect the striations at angles ranging between io and 20 degrees (Fig. 4). All localities are on the crest of the ridge, or on the west slope adjacent to the crest, but many outcrops on the east slope are mantled by rubble, and additional lineation occurrences may be concealed by this cover. The strike of the striations ranges from 250 to 270 degrees, and the average strike of the deep grooves at locality No. 4 is 280 degrees. The attitudes of the striations and grooves are discordant to layering and flow structures in the trachytes.

Weathered and indistinct features similar to chatter marks and friction cracks also occur, but they do not appear to offer definitive evidence for the direction of ice movement.

Stepped outcrops occur on the west slope, adjacent to the crest, which suggest ice quarrying. However, the east dip of the trachyte flows on the summit ridge would encourage quarrying on the west slope whether the ice moved east or west. 
Geomorphological evidence for the direction of ice movement seems to be inconclusive, but the correlation of striation and groove orientations with current ice movement vectors east of the Hut Point peninsula may be significant.

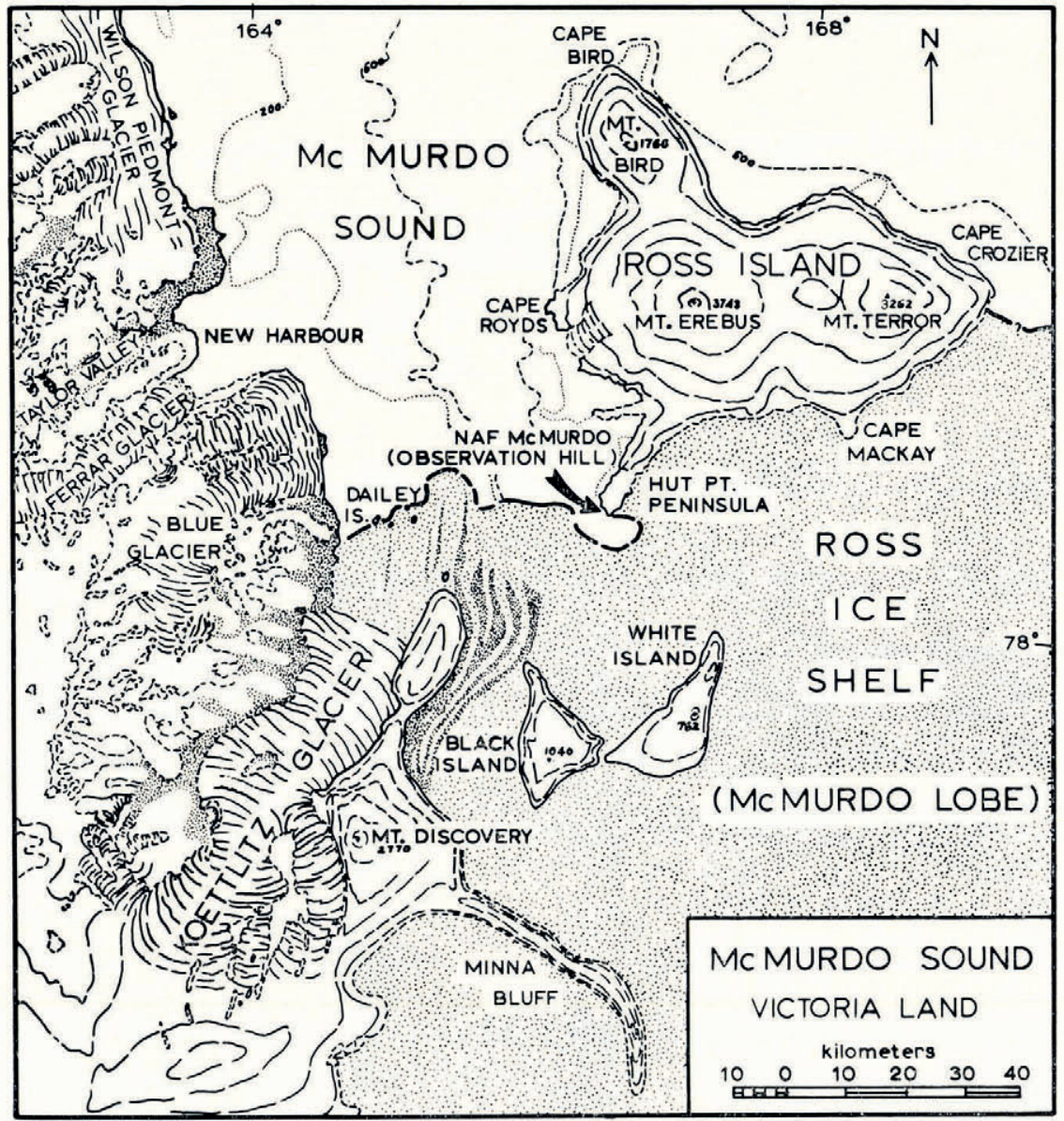

Fig. I. Map of the McMurdo Sound region; based on the 1962 I: 1, ooo, ooo map as compiled and drawn by the American Geographical Society

\section{Parallelism of Glacial Lineations and Ice Shelf Movement Vectors}

We were first impressed by the approximate parallelism of the glacial striations and grooves on Observation Hill to present ice shelf movement directions, when we noted the vectors computed by Macdonald (I96I) from observations made during 1957-58; and more recently, to those presented by Stuart and Bull (1963) for a larger segment of the ice shelf during I959-6o (Fig. 5B). The westernmost part of the McMurdo Ice Shelf is currently moving due west.

This parallelism suggests that Observation Hill was glaciated by an enlarged lobe of the adjacent McMurdo Ice Shelf, moving westward as today. A lobe capable of inundating the $747 \mathrm{ft}$. (227 m.) summit of Observation Hill would have been grounded on the adjacent bottom of McMurdo Sound. The minimal total thickness of such a lobe would probably exceed 


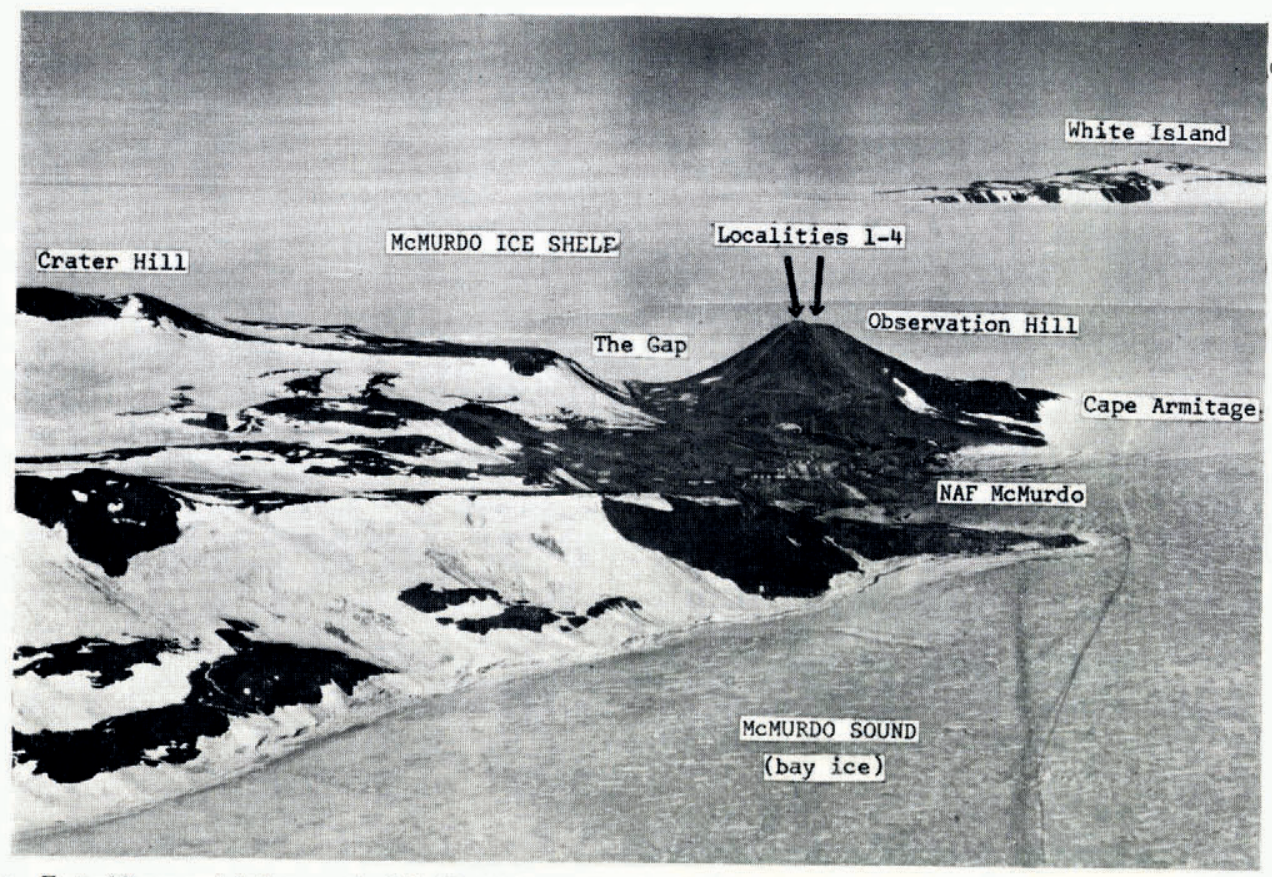

Fig. 2. East oblique aerial photograph of the Hut Point peninsula, from Crater Hill to Cape Armilage. (U.S. Navy photograph)

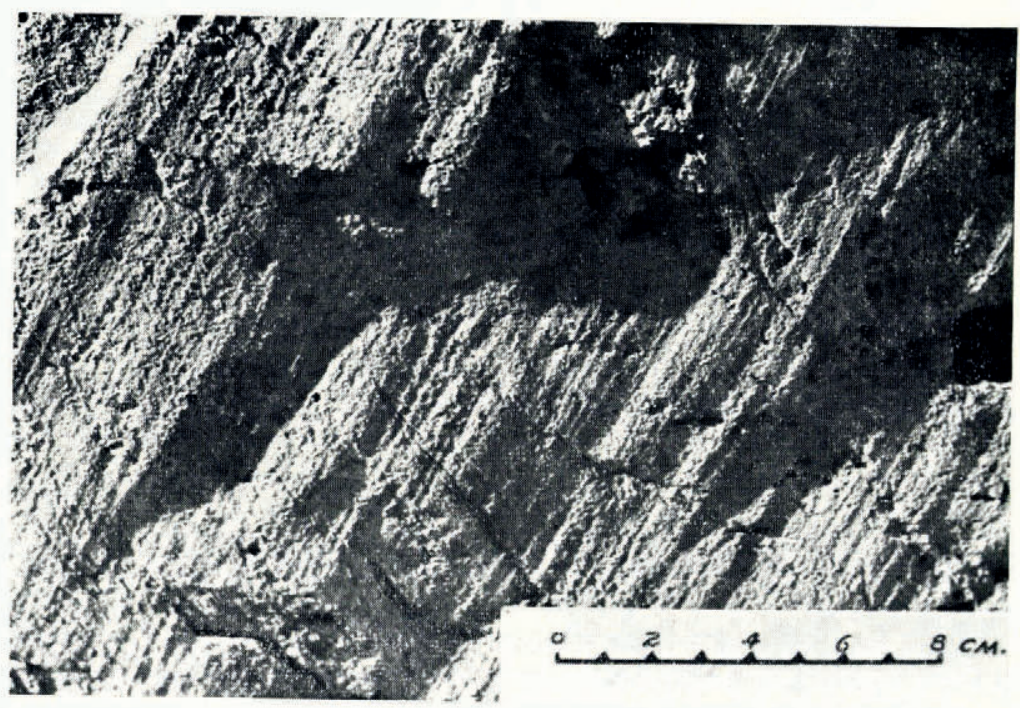

Fïg. 3. Glacial striations; locality. No. 3, Observation Hill 


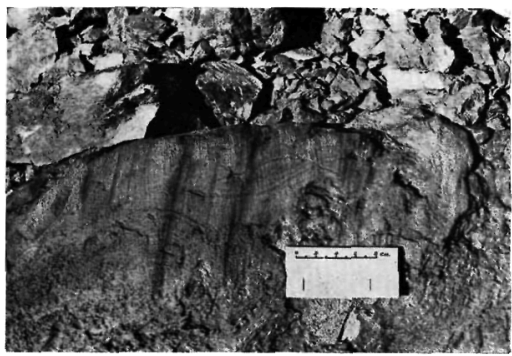

Fig. 4. Glacial striations transected by grooves; locality No. 4, Observation Hill

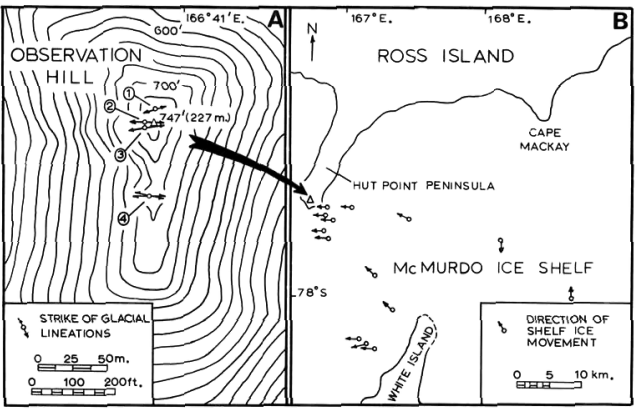

Fig. 5. A. The summit ridge of Observation Hill, showing the localion and orientation of glacial lineations. (Topography from Sheet 7, Naval Air Facility, McMurdo, Antarcica; U.S. Navy Hydrographic Office)

$B$. Ice movement directions for the McMiardo lce Shelf, $1959-60$, as taken from Stuart and Bull ( 1963$)$ 
$800 \mathrm{~m}$. (considering such variables as a possible $\mathrm{r} 5 \mathrm{O} \mathrm{m}$. depression of sea-level during the Würm glaciation, as proposed by Hollin ( 1962 ), and isostatic complications).

An alternative explanation would be glaciation by ice descending from Victoria Land, moving to the east across McMurdo Sound to the Hut Point peninsula. Such a mass, in our opinion, would tend to flow north-east rather than east, and thence north along the axis of the McMurdo Sound embayment (Fig. I).

The glaciation of the $747 \mathrm{ft}$. $(227 \mathrm{~m}$.) summit ridge may correlate with the elevation of moraines containing continental rock types at $800 \mathrm{ft}$. (244 m.) above sea-level, and higher, near Capes Crozier and Royds, to the north and north-east of the Hut Point peninsula on Ross Island (Fig. I). Recently Speden ( I 962) has described glacial striations on an outcrop of tuffaceous sediments containing Quaternary marine fossils, 60o ft. ( $182 \mathrm{~m}$.) above sea-level on Black Island, and moraines at the $800 \mathrm{ft}$. (244 m.) level on Brown Island. However, glacial lineations, erratics and moraines have been widely reported from many localities in the Ross Archipelago, at elevations ranging from sea-level to at least 2,00o ft. (6ro m.) above sea-level, and the glacial history is clearly complex and multicyclic.

Although the glaciation of Observation Hill and the previously cited localitites above Capes Royds and Crozier may represent the same event, no attempt is made here to correlate the glaciation of Observation Hill with one of the four regional glacial stages proposed by previous workers. Péwé (1960) has recognized four successive Quaternary glaciations in the McMurdo Sound region, each less extensive than the former; and Bull and others (I962) have proposed a similar glacial history, based on their studies of the Wright and Victoria
Valley systems.

\section{Regional Implications}

The east-west orientation of the striations and grooves on the summit of Observation Hill may be important to the reconstruction of the glacial history of the region. If westward movement prevailed, as today, and the McMurdo lobe of the Ross Ice Shelf glaciated Observation Hill, the flow of ice from the Victoria Land glaciers, including the Koettlitz Glacier stream, seems to have had little diversionary effect on the flow of the western part of
the McMurdo Ice Shelf.

This possible anomaly suggests that further work should be done to determine whether the maximum development of outlet and alpine glaciers of Victoria Land, west of McMurdo Sound, was in phase with the growth of the ice shelf during the glaciation of Observation Hill. For, if the outlet and alpine glaciers of south Victoria Land were not in phase with the ice shelf maximum, the McMurdo lobe which inundated Observation Hill may have extended across McMurdo Sound to coastal Victoria Land. If the re-entrant valley mouths were ice-free at that time, the ice shelf may have invaded these valleys.

Hollin ( 1962 ) has suggested that glacial fluctuations in Antarctica may be more directly related to changes in sea-level than regional climatic trends, and he has presented convincing theoretical evidence for a probable northward advance of the Ross Ice Shelf, based on a fall in sea-level of I $50 \mathrm{~m}$. during the Würm glaciation. Hollin believes that such a depression of sea-level would ground large areas of the ice shelf, and that decreased ablation by bottom melting plus less calving at the ice shelf edge in a colder and shallower Ross Sea would cause the ice shelf to thicken and advance. In his discussion of the regional implications, Hollin states: "Consider some probable effects of a grounding of the Ross Ice Shelf. First, the appearance of the area would be different; horizontal surfaces would be replaced by complex ones which would rise steeply to one, two or three thousand meters. Secondly, the "dry valleys of Victoria Land would be filled not so much by the frequently postulated 'ice floods from the interior to the west' (though such may have occurred) as by the intrusion of ice lobes from the grounded shelf to the east." 
Nichols (196I) has distinguished three stages of glaciation in the eastern part of the Wright Valley, based on the westward flow of ice from the area presently occupied by the Wilson Piedmont Glacier (Fig. I). Nichols also discovered pectens in stratified gravels in Wright Valley, nearly $40 \mathrm{~km}$. from the present coastline. Bull (1962) states that these glaciations post-date the last continuous glacier which flowed from the inland ice plateau through the Wright Valley to the McMurdo Sound area; and he also cites Hollin's theory of the grounded ice shelf as a possible explanation of the pecten occurrence in Wright Valley. Bull ( 1962 ) states that a grounded ice shelf which attained a parabolic surface profile as proposed by Hollin, would have a surface elevation of about $\mathrm{I}, 200 \mathrm{~m}$. east of the Wright Valley; and that the total ice thickness near the Wilson Piedmont Glacier may have been between I, 500 and 2,000 m. (personal communication from C. Bull). Under such conditions, Bull believes that pectens could have been transported from an area previously occupied by the sea into the Wright Valley, although the glaciers flowing eastward from the inland ice plateau may have experienced little change.

Our findings may reinforce the views of Hollin (1962) and others who have suggested that the Wilson Piedmont Glacier may be a relict of a grounded Ross Ice Shelf, and that the glacial history of the "dry valleys" of Victoria Land may also involve invasion by the ice shelf from the east.

\section{Acknowledgements}

We wish to thank Drs. Troy L. Péwé and Carl Benson, of the Geology Department and the Geophysical Institute, University of Alaska, and Dr. Colin Bull, Institute of Polar Studies, The Ohio State University, for valuable discussions on the regional implications of the Observation Hill glaciation, and for their critical review of the manuscript.

The striation and groove localities were encountered during our work on the petrology of the ultrabasic inclusions in the volcanic rocks of the Hut Point peninsula, as supported by National Science Foundation grant No. G-2366o.

MS. received 23 July 1963

\section{REFERENCES}

Bull, C. 1962. Quaternary glaciations in southern Victoria Land, Antarctica. Journal of Glaciology, Vol. 4, No. 32, p. $240-4$ I. [Letter.]

Bull, C., and others. 1962 . Quaternary glaciations in southern Victoria Land, Antarctica, by C. Bull, B. C. McKelvey and P. N. Webb. Journal of Glaciology, Vol. 4, No. 31, p. 63-78.

David, T. W. E., and Priestley, R. E. 1914. Glaciology, physiography, stratigraphy, and teclonic geology of South Victoria Land. London, William Heinemann. (Reports on the Scientific Investigations of the British Antarctic Expedition, 1907-09. Geology, Vol. 1.)

Debenham, F. 1923. The physiography of the Ross Archipelago. London, Harrison. (British (Terra Nova) Antarctic Expedition, 1910-1913.)

Ferrar, H. T. 1907. Report on the field-geology of the region explored during the "Discovery" Antarctic Expedition, 190I-04. (In Geology. London, British Museum (Nat. Hist.). (National Antarctic Expedition, 1901-1904. Natural History, Vol. i.))

Hollin, J. T. 1962. On the glacial history of Antarctica. Journal of Glaciology, Vol. 4, No. 32, p. 17395.

Macdonald, W. J. P. I 6 I Glaciology. Movement of the Ross Ice Shelf. New Zealand I.G.Y. Antarctic Expeditions, Scott Base and Hallet Station. Bulletin of the New Zealand Department of Scientific and Industrial Research, No. 140 , p. $98-105$.

Nichols, R. L. 1961. Multiple glaciation in the Wright Valley, McMurdo Sound, Antarctica. Abstracts of symposium papers, tenth Pacific Science Congress of the Pacific Science Association, Honolulu, 1961, p. 317.

Péwé, T. L. Ig6o. Multiple glaciation in the McMurdo Sound region, Antarctica-a progress report. Journal of Geology, Vol. 68, No. 5, p. 498-514.

Speden, I. G. 1962. Fossiliferous Quaternary marine deposits in the McMurdo Sound region, Antarctica. New Zealand Journal of Geology and Geophysics, Vol. 5, No. 5, p. 746-77.

Stuart, A. W., and Bull, C. I963. Glaciological observations on the Ross Ice Shelf near Scott Base, Antarctica. Journal of Glaciology, Vol. 4, No. 34, p. 399-414.

Taylor, T. G. 1922. The physiography of the McMurdo Sound and Granite Harbour region. London, Harrison. (British Antarctic (Terra Nova) Expedition, 1910-1913.) 